\title{
HABITAT PREFERENCE OF PHAEOPHYCEAE SPECIES: IYENGARIA STELLATA (BØRGESEN) BØRGESEN (1939) IN GUJARAT COAST (INDIA)
}

Dimpal SANGHVI *, Nandini Ray CHAUDHURY ** and Bhanukumar JAIN **

* Mafatlal Gagalal Science Institute, Department of Botany, Navarangpura, Ahmedabad, Gujarat, India, IN-300009, dimpalsanghvi@gmail.com

** Space Applications Centre, Indian Space Research Organisation, Jodhpur Tekra, Ambavadi Vistar, Ahmedabad, Gujarat, India, IN-380015, nandinirc@sac.isro.gov.in, bkjain_mgsc@yahoo.com

DOI: 10.2478/trser-2019-0002

KEYWORDS: Macroalgae, variation, growth, habitat, shore platform, reef flat.

\section{ABSTRACT}

Many species of phaeophyta are found at Dwarka and at the Bet-Shankhodhar coast, Gujarat, India. For the study of Iyengaria stellata, the shore platform and reef flat were divided into three sections: Dwarka in i) North, ii) Centre and iii) South sections and Bet-Shankhodhar in i) West, ii) Centre and iii) East sections. I. stellata was monitored based on systematic random sampling for two years (April, 2013 to February, 2015). In the months of December and February, I. stellata was recorded with high frequencies of reef, flat zones and shore platforms. When compared to shore platform, the frequency of I. stallata was highest in coral reef and flat zones. This study supports that reef flat is very suitable for growth of I. stellata. I. stellata's growth cycle corresponds with local winter season.

ZUSAMMENFASSUNG: Habitat Präferenzen der Braunalgen-Phaeophyceae-Art Iyengaria stellata (Børgesen) Børgesen (1939) an der Gujarat Küste (Indien).

An der Dwarka und der Bet-Shankhodhar Küste, Gujarat, Indien wurden zahlreiche Braunalgenarten festgestellt. Für die Untersuchungen betreffend die Braunalge Iyengaria stellata, wurde die Küstenplattform und die Riff Flächen in drei Abschnitte eingeteilt: Dwarka in einen i) nördlichen, ii) zentralen und iii) einen südlichen und Bet-Shankhodhar in i) einen westlichen, ii) einen zentralen und iii) einen östlichen Abschnitt. I. stellata wurde mit Hilfe systematischer Stichproben verteilt über zwei Jahre - von April 2013 bis February 2015 untersucht. Die Art wurde jeweils mit hoher Frequenz während der Monate Dezember und Februar in den Bereichen der Riffniederungen und dem Küstensockel festgestellt. Die höchste Frequenz von I. stellata wurde im Vergleich zum Küstensockel in den Flächen der Korallenriffe festgestellt. Die Untersuchung unterstützt die Annahme, dass die Flächen des Riffs für die Entwicklung von I. stellata sehr geeignet sind. Der Wachstumszyklus dieser Art entspricht der lokalen Winterzeit.

REZUMAT: Preferințele de habitat a speciei de algă brună Iyengaria stellata (Børgesen) Børgesen (1939), Phaeophyceae, pe coasta Gujarat (India).

În sectoarele de coastă Dwarka și Bet-Shankhodhar din zona costieră Gujarat, India, au fost găsite numeroase specii de alge brune. Pentru studiul speciei Iyengaria stellata, platforma costieră și câmpul recifelor a fost divizat în trei secțiuni: Dwarka într-o secțiune i) nordică, ii) centrală și iii) sudică și Bet-Shankhodhar într-o secțiune i) vestică, ii) centrală și iii) estică. I. stellata a fost studiată cu ajutorul unor probe de sondaj sistematic pe o perioadă de doi ani (din aprilie 2013 până în februarie 2015). Specia I. stellata a fost găsită cu frecvență mare în luna decembrie și februarie în zona câmpului recifelor, și a platformei costiere. Frecvența cea mai mare a speciei a fost găsită în câmpul recifului coralier față de cea a platformei costiere. Acest studiu confirmă că întinderea recifelor este foarte favorabilă pentru dezvoltarea speciei I. stellata, ciclul ei de creștere corespunzând sezonului local de iarnă. 


\section{INTRODUCTION}

Algae are relatively simple photosynthetic plants with unicellular reproductive structures; they range from unicellular organisms to non-vascular filamentous or thalloid plants (Thahira, 2011).

Seaweeds (macroalgae) are large algae that grow in the marine environment and lack true stems, roots and leaves; they commonly grow on coral reefs, in rocky landscape or at significant depth if sunlight can penetrate through the water above. Most of the seaweeds can be seen thriving in underwater beds floating along the sea surface attached to rocks. (Thahira, 2011)

Seaweeds are biologically and ecologically important in the marine ecosystems. They make a substantial contribution to marine primary production and provide habitat for near shore benthic communities. Seaweeds are key space occupiers of rocky shore and interact with other organisms; hence, they play a key role in overall coastal biodiversity (Satheesh and Wesley, 2012). Seaweeds are well known and have been used since ancient times as food, fodder, fertilizer and also a source of medicinal drugs; today seaweeds are the raw material for industrial production of agar, algin and carrageenan (Manivannan et al., 2009).

Chlorophyta, Phaeophyta and Rhodophyta are major groups of seaweeds. These groups are recognized according to their pigments that absorb light of a particular wavelength which in turn, gives them their characteristic colour of green, brown and red. Out of these three, brown algae (Phaeophyta) are multi-cellular and are found in a variety of different physical forms including crusts and filaments. They contain green pigment such as chlorophyll, brown pigment like fucoxanthin, and gold pigment. (Thahira, 2011)

Numerous species of phaeophyta are found at Dwarka and Bet-Shankhodhar coast in Gujarat, India. Iyengaria stellata has looked very different compared to other species of phaeophyta. It has a dark brown, multi-cellular and semi-stellate, spongy and hollow thallus with hollow projections. Iyengaria stellata possess pronounced antidepressant and an anxiolytic property (Bushra et al., 2014). Chronic administration of Iyengaria stellata yields stimulant effects on hematopoietic system which is very beneficial (Bushra et al., 2014). It has been found to have less density and growth on Dwarka coast, in the shore platform area, and high density and growth in Bet-Shankhodhar coast, in the reef flat area.

The present study concentrates on spatial and seasonal variations of seaweed of Iyengaria stellata (Børgesen) Børgesen, brown alga on Dwarka and Bet-Shankhodhar (or BetDwarka) coast, Gujarat, India.

It was carried out with the following principal objectives: to study the spatial variation of I. stellata in Dwarka and Bet-Shankhodhar; to study the temporal variation of I. stellata in Dwarka and Bet-Shankhodhar; to record the stages of growth of I. stellata with respect to the sampling seasons. 


\section{MATERIALS AND METHODS}

\section{Study area}

For the seaweeds' growth, the geographical, geological, topographical and physical nature of the shore is very important. The rocky and coral reef coasts provide a good platform and stable coastal environments compared to that of soft sediment coasts such as beaches and spits. Shore platform and coral reef represent a case environment where the majority of seaweeds grow with a firm substratum attachment.

The Gujarat coast of India represents the north-western most part of the peninsular India. This coastline occurs within the geographical limits of $20^{\circ} 00^{\prime}-24^{\circ} 45^{\prime} \mathrm{N}$ and $68^{\circ} 00^{\prime}-$ $78^{\circ} 30^{\prime} \mathrm{E}$. It is $1,650 \mathrm{~km}$ long with $164,200 \mathrm{~km}^{2}$ continental shelf (Jha et al., 2009). It extends in the form of four major coastal ecologic components: i) Kori creek ii) Gulf of Kachchh iii) Saurashtra coast from Okha to Porbandar and iv) Gulf of Khambhat.

The substratum is rocky in many parts, which provides suitable environment for macroalgae growth (Chakraborty and Bhattacharya, 2012).

The Saurashtra coast, which runs for an approximate length of $985 \mathrm{~km}$, is characterized by rocky, sandy and muddy intertidal zones, harbouring rich and varied flora and fauna (Gohil and Kundu, 2012). The Gulf of Kachchh (GoK) is the largest coastal habitat in the Gujarat coastal area and contains 42 islands (Jha et al., 2009). It has an approximate length of $1,000 \mathrm{~km}$ and is delimited in the north by the Kachchh region and in the south by the Saurashtra region. The Marine National Park and Marine Sanctuary are situated along the southern shore of the Gulf from Okha and extends eastwards to the vicinity of Khijadia. The islands are fringed with corals, mangroves, mudflats, sandflats, coastal salt marsh, sand and rocky beaches which support great diversity of flora and fauna. (Jha et al., 2009; *, http://www.annauniv.edu/iom/iomour/EIA's\%20gujarat.htm)

The present study was carried out on the shore platform of Dwarka, located on the Suarashtra coast and the coral reef adjacent to Bet-Shankhodhar Island, located on the Kachchh Gulf, to study Iyengaria stellata (Fig. 1). This is about five km north of the mainland of Okhamandal and to the east of Okha port (Fig. 2). Bet-Shankhodhar Island is also known as Bet-Dwarka. The eastern part of the island is comprised of sand-hills and bushes and is known as Hanumandandi point. On this island, 28 hectares' areas were covered by the coral reefs. (Satyanarayana Ramakrishna, 2009)

Geographical location and total area of study sites are given in table 1.

Table 1: Details of area of the study sites Dwarka and Bet-Shankhodhar.

\begin{tabular}{|c|c|c|c|c|c|c|}
\hline $\begin{array}{c}\text { Sr. } \\
\text { no. }\end{array}$ & Sites & \multicolumn{2}{|c|}{$\begin{array}{c}\text { Geographical } \\
\text { location }\end{array}$} & \multicolumn{3}{c|}{$\begin{array}{c}\text { Total } \\
\text { study area }\end{array}$} \\
\hline & Latitude & Longitude & $\begin{array}{c}\text { Length } \\
\text { (m) }\end{array}$ & $\begin{array}{c}\text { Maximum } \\
\text { width (m) }\end{array}$ & $\begin{array}{c}\text { Surface } \\
\text { area }\left(\mathrm{m}^{2}\right)\end{array}$ \\
\hline 1 & Dwarka & $\begin{array}{c}22^{\circ} 14^{\prime} 22^{\prime \prime} \mathrm{N} \\
\text { to } \\
22^{\circ} 14^{\prime} 38^{\prime \prime} \mathrm{N}\end{array}$ & $\begin{array}{c}68^{\circ} 57^{\prime} 15^{\prime \prime} \mathrm{E} \\
\text { to } \\
68^{\circ} 57^{\prime} 25^{\prime \prime} \mathrm{E}\end{array}$ & 572.28 & 143.8 & $82,293.86$ \\
\hline 2 & $\begin{array}{c}\text { Bet- } \\
\text { Shankhodhar }\end{array}$ & $\begin{array}{c}22^{\circ} 28^{\prime} 14^{\prime \prime} \mathrm{N} \\
\text { to } \\
22^{\circ} 28^{\prime} 56^{\circ} \mathrm{\prime} \mathrm{N}\end{array}$ & $\begin{array}{c}68^{\prime} 17^{\prime \prime} \mathrm{E} \\
\text { to } \\
68^{\circ} 09^{\prime} 76^{\prime \prime} \mathrm{E}\end{array}$ & 1606.45 & 338.5 & $543,783.33$ \\
\hline
\end{tabular}




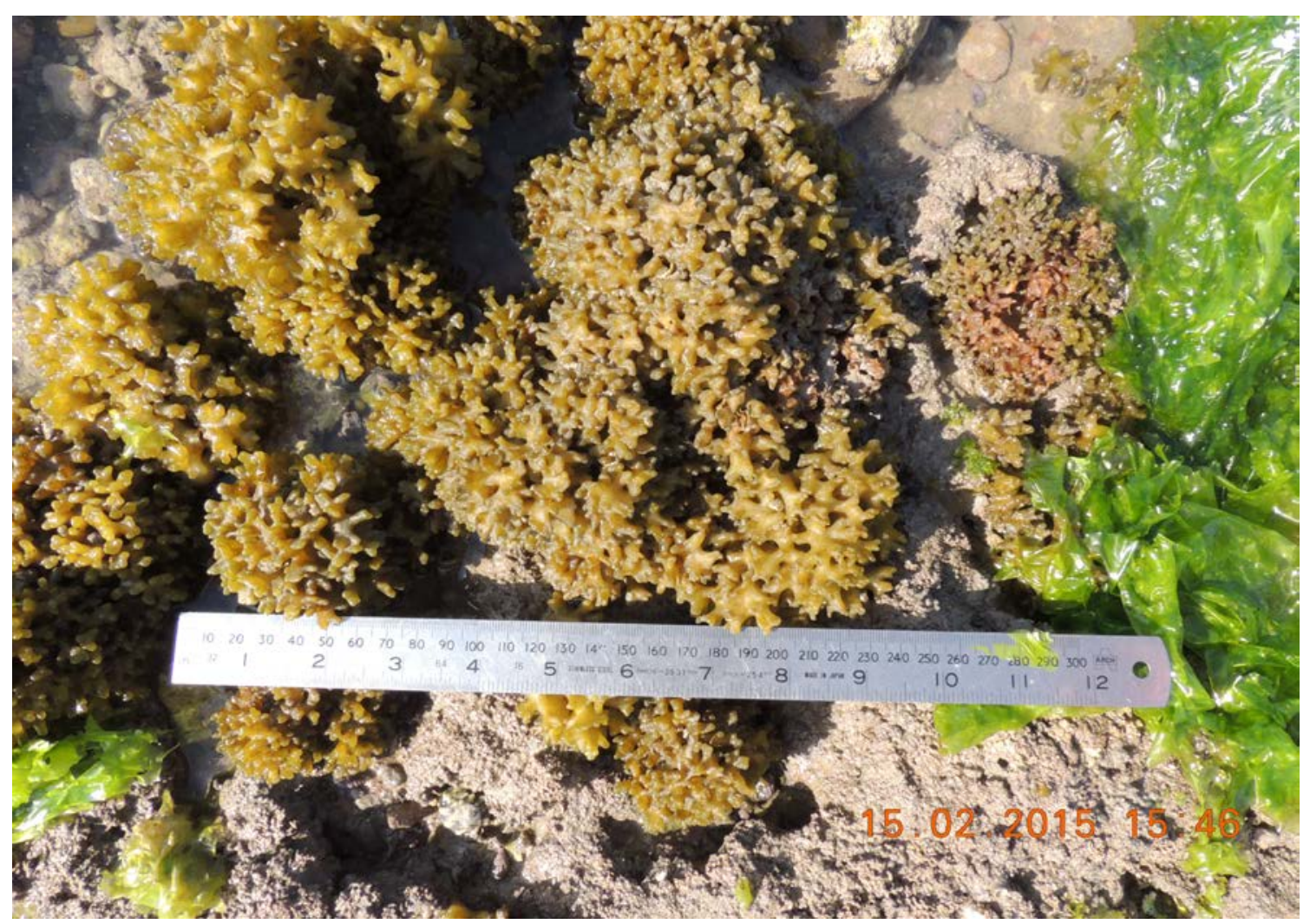
Figure 1: Iyengaria stellata.
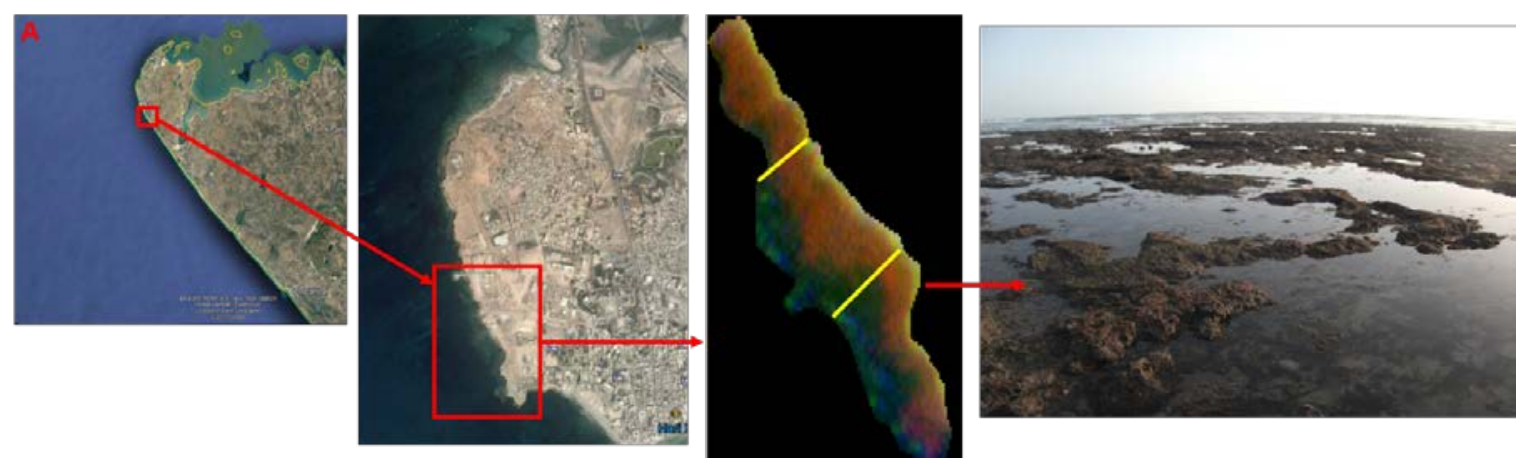

Figure 2a: Shore Platform, Dwarka.
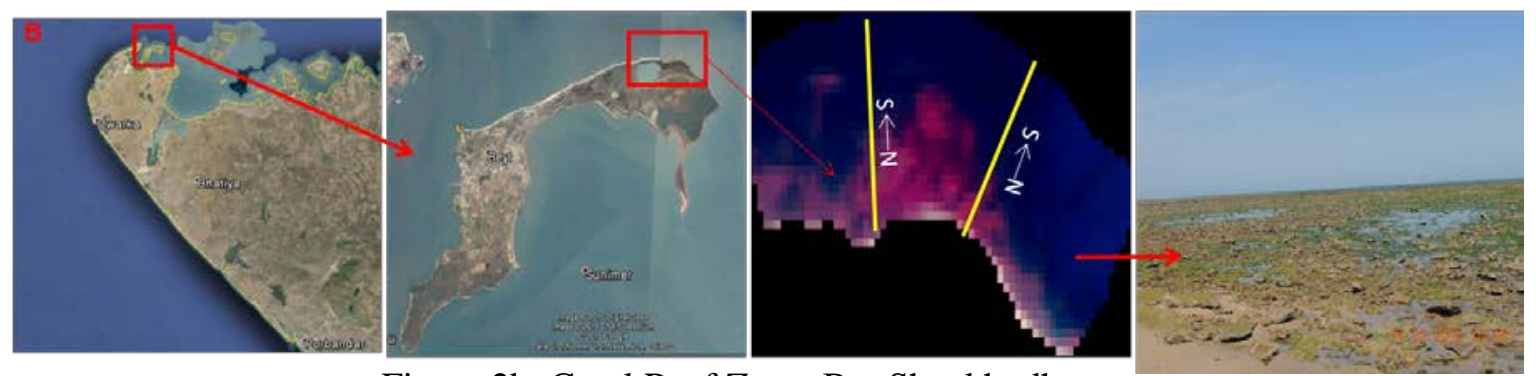

Figure 2b: Coral Reef Zone, Bet-Shankhodhar. 


\section{Field data collection}

For the study of I. stellata, the shore platform of Dwarka was divided into three sections (in North-South direction): i) Northern, ii) Central, and iii) Southern; BetShankhodhar was also divided into three sections (in East-West direction): i) Western ii) Central, and iii) Eastern for convenience of field sampling. Field sampling of seaweeds was done from April, 2013 to February, 2015 (April, June, October, and December, 2013; December, 2014, and February, 2015). Field survey and/or sampling were performed during the low tides. For qualitative and quantitative assessment, the GPS (Spheroid and Datum: WGS 84) tagged line transect.

Maximum and minimum transect length survey and maximum depth of the subtidal zone sampled for macroalgae are given in table 2 for Dwarka and Bet-Shankhodhar. Length of transect lines depended on the tidal exposure of the shore platform during the field surveys.

Table 1: Information about transect length and depth of subtidal zone of Dwarka and Bet-Shakhodhar.

\begin{tabular}{|c|c|c|c|c|}
\hline $\begin{array}{c}\text { Sr. } \\
\text { no. }\end{array}$ & $\begin{array}{c}\text { Study } \\
\text { site }\end{array}$ & $\begin{array}{c}\text { Maximum transect } \\
\text { length }(\mathrm{m})\end{array}$ & $\begin{array}{c}\text { Minimum transect } \\
\text { length }(\mathrm{m})\end{array}$ & $\begin{array}{c}\text { Maximum depth of } \\
\text { the subtidal zone }\end{array}$ \\
\hline 1 & $\begin{array}{c}\text { Dwarka } \\
\text { Coast }\end{array}$ & 143.8 & 24 & 0.5 \\
\hline 2 & $\begin{array}{c}\text { Bet-Shankhodhar } \\
\text { Coast }\end{array}$ & 338.5 & 52 & 1 \\
\hline
\end{tabular}

For quantitative assessment of the $I$. stellata in the given area, line transects was laid perpendicular to the coast from land to sea with the help of a long rope (50 m) (Dhargalkar and Kavlekar, 2004). A sampling point along the rope is marked depending on the gradient and exposure of intertidal and subtidal areas. In Saurashtra coast, the tidal amplitude is very high as compared to other parts of the western coast and the entire east coast of India (Jha et al., 2009). Growth of seaweeds in intertidal and shallow subtidal regions can be easily observed in this area as the spring tides expose the intertidal area up to a maximum length of one km (Jha et al., 2009). Each of the three sections at Dwarka and Bet-Shankhodhar were represented by one transect line and quadrates of one $\mathrm{m}^{2}$ were positioned on the transect lines. Wherever the algae growth, density and diversity were high (Tab. 3). GPS tagged photos of quadrates were taken for further analysis. Seaweeds present within the quadrates were sampled. All specimens were identified and the specific numbers of individuals were registered for quantitative assessment of frequency.

Table 2: Total transects lines and quadrates on study sites.

\begin{tabular}{|c|c|c|c|}
\hline $\begin{array}{c}\text { Sr. } \\
\text { no. }\end{array}$ & Study sites & Total transect Lines & Total quadrates \\
\hline 1 & $\begin{array}{c}\text { Dwarka } \\
\text { Coast }\end{array}$ & 18 & 111 \\
\hline 2 & $\begin{array}{c}\text { Bet-Shankhodhar } \\
\text { Coast }\end{array}$ & 13 & 83 \\
\hline
\end{tabular}




\section{Field data analysis}

For the study of I. stellata, collected seaweeds samples from the field were taken to the laboratory for preparation of herbarium sheets and specimen identification. Morphological criteria were analysed for taxa identification. To understand their spatial variation, quadrate data was analysed and were graphically represented as cross profile on shore platform and coral reef with embedded bar charts showing frequency of different months. Frequency of I. stellata encountered at the transect intercepts is represented as bar charts. X-axis of the bar chart represents in which months and sections $I$. stellata present while Y-axis shows their respective frequencies (in percentage) (Figs. 2 and 3).
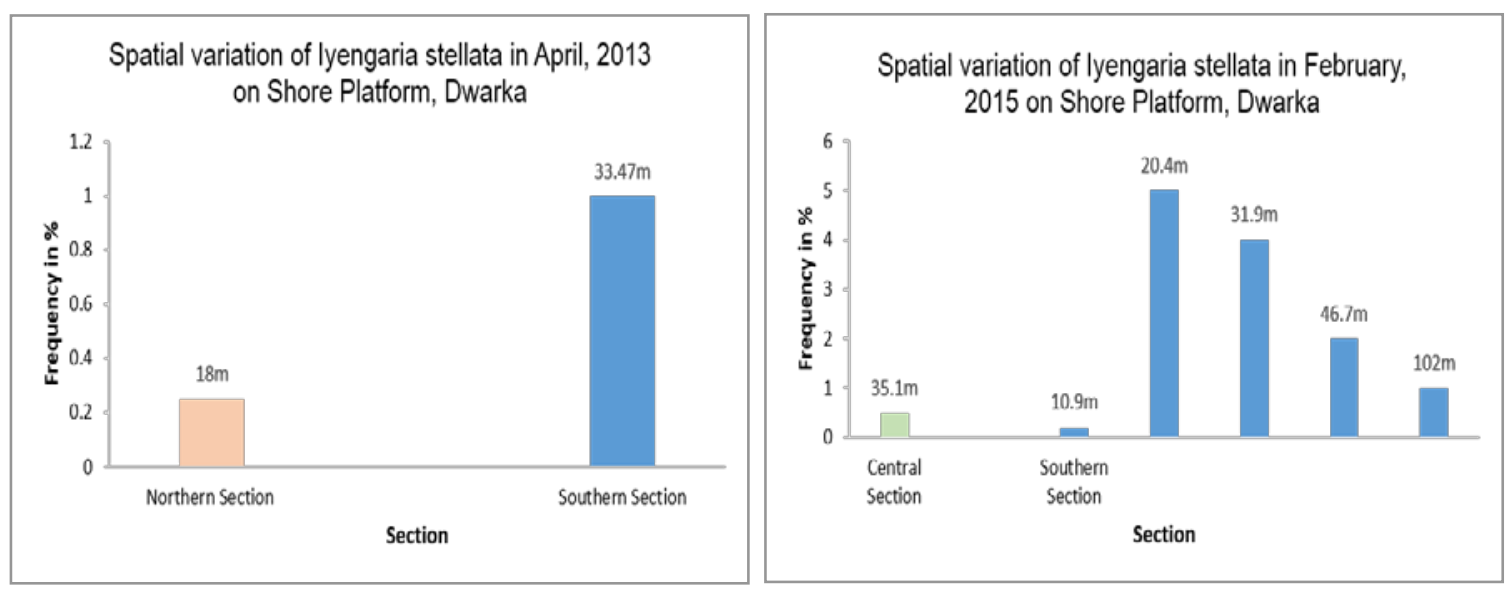

Figure 2: Spatial variation of I. stellata on Shore Platform, Dwarka.
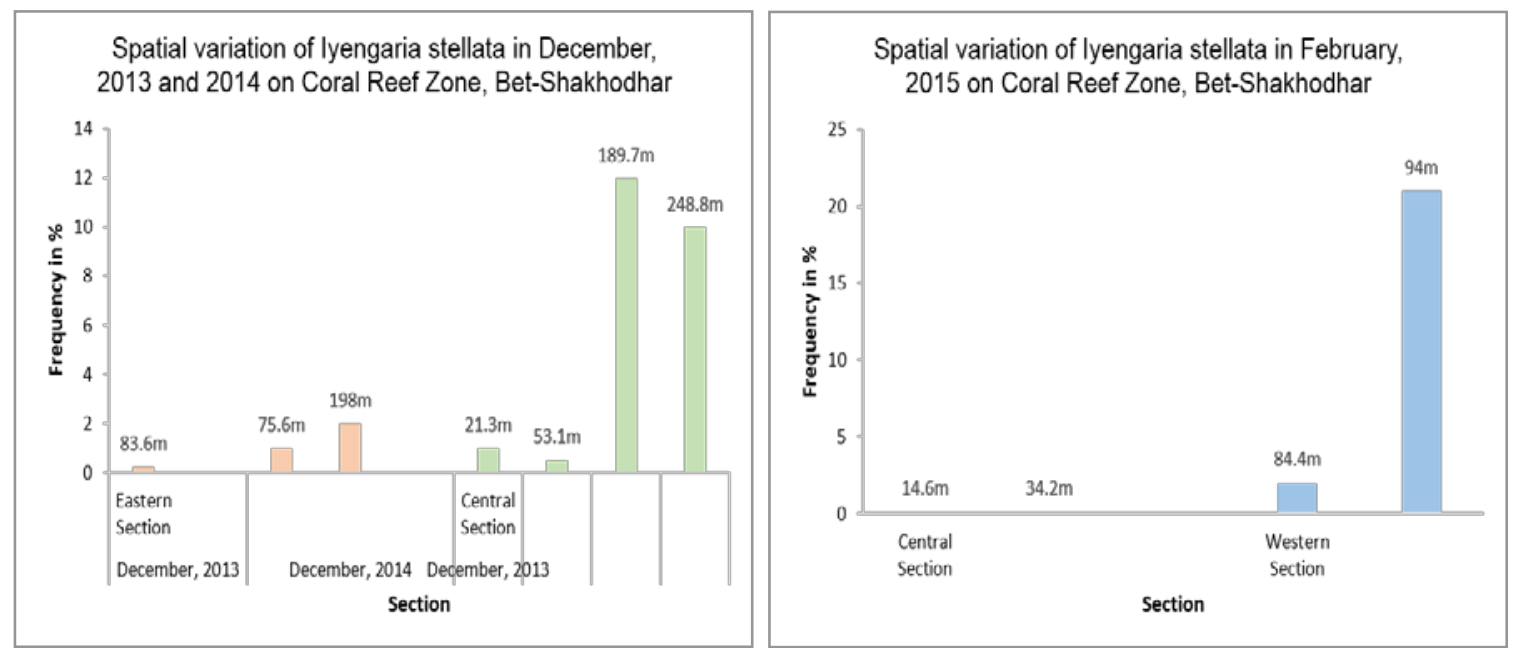

Figure 3: Spatial variation of I. stellata on Coral Reef Zone, Bet-Shankhodhar. 


\section{RESULTS AND DISCUSSION}

Shore platform and coral reef zones

From the field data, it emerged that the shore platform and coral reef flat can be divided into three zones (in North-South direction and East-West direction respectively) based on areas the groups of seaweed were observed. The shore platform and reef flat can be divided into: i) cliff base part, ii) an intertidal mixed zone, and iii) a subtidal zone from the land to the sea. In shore platform, it was found that phaeophyta in rock pools (these pools were found in less numbers in the northern section) dominate the cliff base zone. The cliff base is followed by a mixed intertidal area, where there is a transition from phaeophyta (dominant in the intertidal zone) to chlorophyta (dominant in the subtidal zone). The subtidal zone dominated by chlorophyta, is found at the seafront.

In the case of coral reef flat, it was found that phaeophyta dominates in land front and chlorophyta and rhodophyta is dominated in subtidal zone. The intertidal zone is again a mixed zone (followed phaeophyta to chlorophyta and rhodophyta).

Spatial variation of I. stellata

As discussed the shore platform and coral reef flats were divided into three sections for the convenience of field sampling: the results are reported here section wise.

Shore platform: Dwarka

Northern section

Transect and quadrate data sampled for I. stellata during two years (April, 2013 to February, 2015) of field survey are represented in table 4 and figure 2. During April, 2013 profile $I$. stellata was recorded at $18 \mathrm{~m}$ with $25 \%$ frequency. In other months I. stellata was not detected in northern section.

Central section

Transect and quadrate data sampled for I. stellata during two years (April, 2013 to February, 2015) of field survey are represented in table 4 and figure 2. During February, 2015 profile I. stellata was observed at $35.1 \mathrm{~m}$ with $0.5 \%$ frequency. In other months I. stellata was not detected in the central section.

\section{Southern section}

Transect and quadrate data sampled for I. stellata during two years (April, 2013 to February, 2015) of field survey are represented in table 4 and figure 2. During April, 2013 profile I. stellata was found at $33.47 \mathrm{~m}$ with $1 \%$ frequency. In February profile I. stellata was recorded at $10.9 \mathrm{~m}$ (0.2\%), $20.4 \mathrm{~m}$ (5\%), $31.9 \mathrm{~m}$ (4\%), $46.7 \mathrm{~m}$ (2\%), $102 \mathrm{~m} \mathrm{(1 \% ).} \mathrm{In} \mathrm{February}$ profile, frequency was increased at $10.9 \mathrm{~m}$ to $20.4 \mathrm{~m}$ and at $31.9 \mathrm{~m}$ to $102 \mathrm{~m}$, frequency got decreased. In other months I. stellata was not detected in the southern section. I. stellata was found highest in the southern section.

Coral reef zone: Bet-Shankhodhar

Western section

Transect and quadrate data sampled for I. stellata during two years (April, 2013 to February 2015) of field survey are showed in table 4 and figure 3. During February profile $I$. stellata was observed at $84.4 \mathrm{~m} \mathrm{(2 \% )}$ and $94 \mathrm{~m}$ (21\%) with increased frequency. In the months April and June, I. stellata was not recorded; data was not available for October and December months. In western section I. stellata was recorded with highest frequency. 
Central section

Transect and quadrate data sampled for I. stellata during two years (April, 2013 to February, 2015) of field survey are represented in table 4 and figure 3. During December, 2013 profile $I$. stellata was found at $21.3 \mathrm{~m}$ and $53.1 \mathrm{~m}$ with less frequency and at $189.7 \mathrm{~m}$ and $248.8 \mathrm{~m}$, it was recorded with high frequency. In February, I. stellata was recorded at $14.6 \mathrm{~m}$ and $34.2 \mathrm{~m}(0.1 \%)$ with same frequency. Data was not seen in December, 2014 and in other months, I. stellata was not present.

Eastern section

Transect and quadrate data sampled for I. stellata during two years (April, 2013 to February, 2015) of field survey are represented in table 4 and figure 3. In December, 2013 profile I. stellata was recorded at $83.6 \mathrm{~m}$ with $0.25 \%$ frequency and in December, 2014 I. stellata was recorded at $75.6 \mathrm{~m}$ and $198 \mathrm{~m}$ with $1 \%$ and $2 \%$ frequency respectively. In April, June and October, I. stellata was absent and in February, data was not available.

Table 4: Frequency of I. stellata based on line transects and quadrate survey on the shore platform, Dwarka and coral reef zone, Bet-Shankhodhar.

\begin{tabular}{|c|c|c|c|c|}
\hline $\begin{array}{l}\text { Study } \\
\text { sites }\end{array}$ & Month & Sections & $\begin{array}{c}\text { Frequency } \\
\text { (\%) }\end{array}$ & $\begin{array}{l}\text { Quadrate Distance } \\
\text { on transects (m) }\end{array}$ \\
\hline \multirow{8}{*}{ Dwarka } & \multirow{2}{*}{ April, 2013} & $\begin{array}{c}\text { Northern } \\
\text { section }\end{array}$ & 0.25 & 18 \\
\hline & & $\begin{array}{c}\text { Southern } \\
\text { section }\end{array}$ & 1 & 33.47 \\
\hline & \multirow{6}{*}{ February, 2015} & $\begin{array}{l}\text { Central } \\
\text { section }\end{array}$ & 0.5 & 35.1 \\
\hline & & \multirow{5}{*}{$\begin{array}{l}\text { Southern } \\
\text { section }\end{array}$} & 0.2 & 10.9 \\
\hline & & & 5 & 20.4 \\
\hline & & & 4 & 31.9 \\
\hline & & & 2 & 46.7 \\
\hline & & & 1 & 102 \\
\hline \multirow{12}{*}{$\begin{array}{c}\text { Bet- } \\
\text { Shankhodhar }\end{array}$} & December, 2013 & \multirow{4}{*}{$\begin{array}{l}\text { Eastern } \\
\text { section }\end{array}$} & 0.25 & 83.6 \\
\hline & \multirow[b]{3}{*}{ December, 2014} & & - & - \\
\hline & & & 1 & 75.6 \\
\hline & & & 2 & 198 \\
\hline & \multirow{4}{*}{ December, 2013} & \multirow{4}{*}{$\begin{array}{l}\text { Central } \\
\text { section }\end{array}$} & 1 & 21.3 \\
\hline & & & 0.5 & 53.1 \\
\hline & & & 12 & 189.7 \\
\hline & & & 10 & 248.8 \\
\hline & \multirow{4}{*}{ February, 2015} & \multirow{2}{*}{$\begin{array}{l}\text { Central } \\
\text { section }\end{array}$} & 0.1 & 14.6 \\
\hline & & & 0.1 & 34.2 \\
\hline & & \multirow{2}{*}{$\begin{array}{l}\text { Western } \\
\text { section }\end{array}$} & 2 & 84.4 \\
\hline & & & 21 & 94 \\
\hline
\end{tabular}




\section{Temporal variation of $I$. stellata}

Temporal variation of $I$. stellata in the three sections of shore platform, Dwarka are presented in table 4 and figure 4 . In the northern section, a total of twenty-nine quadrates were studied in the six sampling months, while in the central section thirty-eight quadrates were studied and for the southern section forty-four were studied. In the northern and central sections I. stellata was found highest in April and was highest in the southern section in February. On shore platform I. stellata was highly recorded in the February, while during in June to November it was absent.

Temporal variation of I. stellata in section three of coral reef zone, Bet-Shankhodhar is presented in table 4 and also in figure 4. In eastern section, total thirty-one quadrates were studied in the six sampling months, while in central section thirty-four quadrates were studied and for western section eighteen were studied. In central section I. stellata was found with highest values in December and in western section in February. I. stellata was absent from June to October. So, we found that I. stellata grows during January to February.

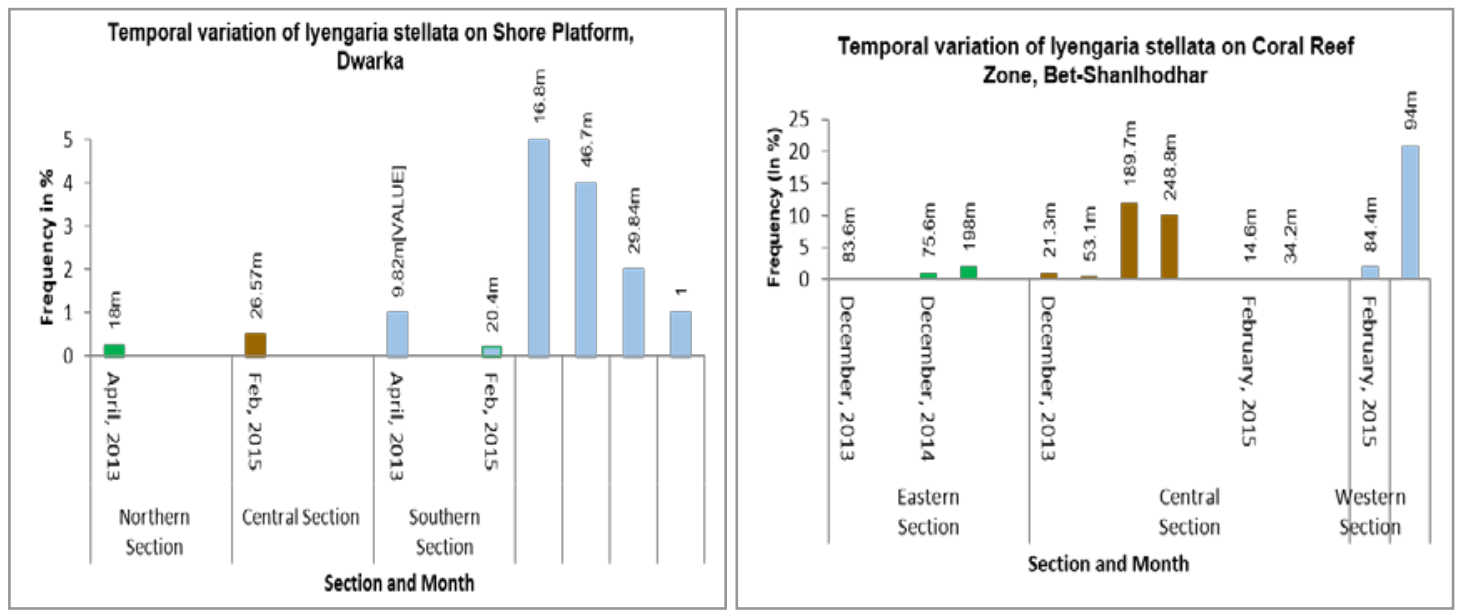

Figure 4: Temporal variation of I. stellata on Shor platform, Dwarka and coral reef zone, Bet-Shankhodhar.

Stage of growth of I. stellata

On the shore platform of Dwarka and reef flat zone of Bet-Shankhodhar, the occurrence of I. stellata was noted during six sampling months. Out of these six months, I. stellata was only found between December to April. The highest frequency was recorded in February and I. stellata decreased in April.

The present study shows the presence of I. stellata from December to April and growth in full phase in February on the shore platform. On reef flat zone I. stellata was present in November-March period growing in full phase in January and February. Density of I. stellata was higher in reef flat of Bet-Shankhodhar as compared to shore platform of Dwarka. 
Numerous researchers have studied the distribution of marine macroalgae on seasons in India. They researched seasonal variation of macroalgae in the east and west coasts but not the I. stellata growth cycle. Usmanghani et al. (1987) has worked on the sterols of a brown seaweed I. stellata from Pakistan. They were studied for sterol composition of I. stellata; they found two sterols (ergosterol and cholesterol) for the first time from brown seaweed. Bushra et al. (2014) has studied an evaluation of nephrotoxic potential of $I$. stellata. The species was very effective on renal function. They gave one dose every thirty days of $I$. stellate to rabbits and the level of urea and creatinine measured showed an increased level of urea after continued administration of I. stellate. I. stellata has nephroprotective effect.

Kesava Roa and Singbal (1995) have worked on the seasonal variation in halides and their ratio were estimated in three marine brown algae, namely Cystoseira indica (Thivy and Doshi) Mairh, Sargassum tenerrimum Agardh J. G. and Sargassum johnstonii Setchell and Gardner from Porbandar and Okha coasts (NW coast of India). Halides were found higher in early stages of growth in this study. This study showed Br: F (Bromine: Fluoride) ratio was higher in the reproductive stage indicating that algae tend to accumulate $\mathrm{Br}$ compared to $\mathrm{F}$ during this stage than at early and senescent stages, though $\mathrm{Br}$ level in ambient medium is not a limiting factors. Bhanderi and Trivedi (1975) have worked on the seaweed resources of Hanumandandi Reef and Vumani Reef near Okha Port, Gujarat. This study computed quantities of seaweeds peak periods of the growth and projected twice proper for harvesting of each economic seaweed. In this study, edible seaweeds, the two species of genus Ulva, i.e. Ulva lactuca Linnaeus and Ulva fasciata Delile, were available in maximum quantity in different months on Hanumandandi reef, while on Vumani reef. Only $U$. fasciata was available throughout the season and the maximum availability was 9.077 tons in February, 1974. The peak period of growth was observed during October, 1973 and February, 1974 on Vumani Reef while it was only observed in March, 1974 on Hanumandandi reef. Agarophytes and iodine-yielding algae were less on both the reefs as compared to the edible seaweeds. Maximum availability of agarophytes was estimated in January, 1974 on Hanumandandi reef. On Vumani reef, different agarophytes species showed peak growth in different months. Iodine-yielding plants were observed maximum on both reefs in December, 1993.

This study reports seasonal, temporal and growth stages of I. stellata on the basis of systematic field inventory. This kind of study, when done on routine annual basis, can bring out the variability on spatial and temporal/seasonal province for the study area. Additionally, same species have been spotted and identify on paga and pirotan.

\section{CONCLUSIONS}

This study shows the frequency of I. stellata is high on reef flat zone as compared to shore platform. Reef flat zone is very suitable for growth of $I$. stellata. Its growth cycle is in the winter. This study is to help further studies about $I$. stellate, because it is an important species for extraction of two type of sterols used for pharmaceutic/medicinal purposes. 


\section{ACKNOWLEDGEMENTS}

Authors are thankful to Kamboj R. D., Chief Conservator Officer, Marine National Park (MNP), Jamnagar P. T. Sihani Range Forest Officer, MNP, Dwarka and Kamlesh Chudasma, Forest Guard, MNP, Dwarka for necessary permission and support towards working on the shore platform of Dwarka and reef flat zone of Bet-Shankhodhar. Dimpal is thankful to Chhaganbhai, staff, MNP, Dwarka for supporting in the field work.

We are thankful to Director, Space Applications Centre (SAC), Indian Space Research Organisation (ISRO), Ahmedabad for their constant encouragement and support to carry out this research. Dr. Singh R. P., Head, Environment and Hydrology Division, SAC, ISRO, Ahmedabad is thanked for his support to pursue this research. 


\section{REFERENCES}

1. Bhanderi P. P. and Trivedi Y. A., 1975 - Seaweed resources of Hanumandandi Reef and Vumani Reef near Okha port, Gujarat, Indian Journal of Marine Sciences, 4, 97-98.

2. Bushra R., Rahila N., Sana S., Humera A. and Khan S. S., 2014 - Evaluation of nephrotoxic potential of I. stellata, World Journal of Pharmaceutical Science, 2, 5, 516-519.

3. Chakraborty S. and Bhattacharya T., 2012 - Nutrient composition of marine benthic algae found in the Gulf of Kutch coastline, Gujarat, India, Journal of Algal Biomass Utilization, 3, 1, 32-38, ISSN: 2229-6905.

4. Dhargalkar V. K. and Kavlekar D., 2004 - Seaweeds - a field manual, Verlecar X. N. and Rathod V. (eds), National Institute of Oceanography, Goa, 42.

5. Gohil B. and Kundu R., 2012 - Diversity of the intertidal macro fauna at west coast of Gujarat, India, Life Sciences Leaflet, 12, 135-145.

6. Jha B., Reddy C. R. K., Thakur M. C. and Umamaheswara Rao M., 2009 - Seaweeds of India the diversity and distribution of seaweeds of Gujarat coast, Springer Dordrech Heidelberg London New York, 215, DOI:10.1007/978-90-481-2488-6, http://dx.doi.org/10.1007/978-90481-2488-6.

7. Kesava Rao C. and Singbal S. Y. S., 1995 - Seasonal variations in halides marine brown algae from Porbandar and Okha coasts (NW coast of India), Indian Journal of Marine Sciences, 24, 137-141.

8. Manivannan K., Thirumaran G., Karthikai Devi G., Anantharaman P. and Balasubramanian T., 2009 - Proximate composition of different group of seaweeds from Vadalai coastal waters (Gulf of Mannar), Southeast coast of India, Middle-east Journal of Scientific Research, 4, 2, 72-77, www.idosi.org/mejsr/mejsr4(2)/4.pdf.

9. Satheesh S. and Wesley S. G., 2012 - Diversity and distribution of seaweeds in the Kudankulam coastal waters, South-Eastern coast of India, Biodiversity Journal, 3, 1, 79-84.

10. Satyanarayana Ramakrishna C., 2009 - Handbook on hard corals of Gulf of Kachchh, Zoological Survey of India, Kolkata, 114.

11. Thahira B. A., 2011 - Nutrient composition, antioxidant activity and therapeutic uses of selected seaweeds, Ph.D. thesis, Avinashilingan Deemed University for Women, shodhganga.inflibinet.ac.in/jspui/bitstream/.../07_chapter2.pdf

12. Usmanghani K., Shameel M., Siddiqui S. and Alam M., 1987 - Studies on the sterols of a brown seaweed, I. stellata from Pakistan, Pakistan Journal of Botany, 19, 2, 249-252.

13. *, http://www.annauniv.edu/iom/iomour/EIA’s\%20gujarat.htm 